\title{
KEBUTUHAN AKTIVITAS HIDUP SEHARI-HARI \\ PADA KLIEN LANJUT USIA YANG TINGGAL DI PANTI WERDA TRESNA ABDI DHARMA ASIH BINJAI
}

\author{
Solihuddin Harahap \\ Jurusan Keperawatan Poltekkes Kemenkes Medan
}

\begin{abstract}
Abstrak
Kebutuhan aktivitas sehari-hari lanjut usia adalah sesuatu yang diperlukan oleh seorang lanjut usia baik aktivitas primer, aktivitas rumahtangga, aktivitas waktu luang. Penelitian ini menggunakan metode penelitian deskriptif yang bertujuan untuk melihat gambaran kebutuhan aktivitas hidup sehari-hari klien lanjut usia di Panti Werda Abdi Dharma Asih Binjai. Penelitian ini dilakukan dengan jumlah sampel sebanyak 38 orang. Sampel diambil dengan teknik simple random sampling

Hasil penelitian ini menunjukkan berdasarkan karakteristik responden mayoritas berusia 60-74 tahun $(71 \%)$ dengan rata-rata usia 71 tahun $(\mathrm{SD}=5,83)$, responden pria $(55 \%)$, agama Islam $(82 \%)$, dan suku Jawa (50\%), pendidikan SD (37\%) dan yang tidak sekolah (32\%), pekerjaan sebelumnya wiraswasta (42\%) dan sebahagian lagi adalah petani $(40 \%)$.

Berdasarkan hasil penelitian untuk kebutuhan aktivitas sehari-hari lanjut usia (100\%) responden memberikan respon bahwa kebutuhan akan aktivitas primer yang terbesar yang mereka butuhkan adalah makan 3 kali sehari dengan mendapat makanan tambahan pagi dan sore, kegiatan mandi, menggunakan toilet duduk dan toilet jongkok yang disekitarnya di buat pegangan untuk buang air kecil dan buang air besar, diberi kesempatan melakukan kegiatan ibadah sesuai keyakinan masing-masing, dan tersedianya sarana pemeriksaan kesehatan dan pemberian vitamin perbulannya.

Untuk aktivitas rumahtangga seluruh responden (100\%) menyatakan mereka membutuhkan untuk selalu berkumpul bersama dan bercerita dengan teman sepanti, sedangkan untuk aktivitas waktu luang seluruh responden (100\%) menyatakan menyalurkan kegemaran berolahraga dengan fasilitas yang ada dipanti werda seperti senam taichi, senam yoga, dan meditasi menjadi prioritas utama dari kebutuhan aktivitas sehari-hari dalam aktivitas waktu luang.

Penelitian ini hanya dilakukan di Panti Werda Tresna Abdi Dharma Asih Binjai maka hasil penelitian tidak dapat mewakili kebutuhan aktivitas hidup sehari-hari lanjut usia yang tinggal dipanti werda yang berada di Sumatera Utara, oleh karena itu, sebaiknya pada penelitian selanjutnya diteliti tentang kebutuhan aktivitas hidup sehari-hari lanjut usia yang ada dipanti werda di daerah Sumatera Utara.
\end{abstract}

Kata Kunci : Kebutuhan Aktivitas Sehari-hari, Lanjut Usia, Panti Werda

\section{PENDAHULUAN}

Lanjut usia (Lansia) adalah Kelompok penduduk yang berumur 60 tahun atau lebih (WHO, 1965). Saat ini, di seluruh dunia jumlah lanjut usia diperkirakan mencapai 500 juta dan diperkirakan pada tahun 2025 akan mencapai 1,2 milyar. Di Indonesia sendiri pada tahun 2000, jumlah lanjut usia meningkat mencapai 9,99\% dari seluruh penduduk Indonesia (22.277.700 jiwa) dengan umur harapan hidup usia 6570 tahun dan pada tahun 2020 diperkirakan akan mencapai 30 juta orang dengan umur harapan hidup 70-75 tahun (Badan Penelitian Statistik, 1992). Sedangkan di Sumatera Utara penduduk lanjut usia juga meningkat pesat, yang menurut data BPS pada tahun 2000 dilaporkan bahwa jumlah penduduk Kota Madya Medan sebesar 2.064.900 jiwa atau 13,5\% terdapat 278.895 jiwa penduduk lanjut usia (Suryadi, 1999; Nugroho,1999; Darmojo,1995).

Mundiharno (1997), menyebutkan bahwa peningkatan persentase penduduk lanjut usia membawa implikasi terhadap berbagai sektor pembangunan lainnya. Pergeseran struktur penduduk dari muda ke tua tersebut antara lain berdampak terhadap perubahan kebijakan pemerintah tidak saja di sektor kependudukan tetapi juga di sektor kesehatan/sosial dan bahkan kesektor ekonomi. Hal ini tentunya membawa implikasi pada kebijakan yang dibuat harus dapat mengakomodasi keberadaan lanjut usia derngan segala karakteristiknya baik dari aspek demografi, sosial, dan ekonomi. Faktor-faktor seperti demogafi, sosial, dan ekonomi banyak melatarbelakangi lanjut usia melakukan aktivitas yang beragam baik yang bernilai ekonomi maupun yang tidak bernilai ekonomi. 
Konsep "menua sehat" merupakan tujuan hidup manusia, disini yang terpenting adalah promosi peningkatan kesehatan dan pencegahan penyakit yang harus dimulai sedini mungkin dengan cara dan gaya hidup sehat. Healthy aging ("menua sehat") dipengaruhi oleh berbagai faktor diantaranya adalah kemampuan lanjut usia di dalam memenuhi kebutuhan aktivitas hidup sehari-hari.

Masalah kesehatan lanjut usia tidak terjadi begitu saja, tetapi melalui proses kemunduran yang panjang. Ketika kemunduran fisik dan mental terjadi secara perlahan dan bertahap dan pada waktu kompensasi terhadap penurunan ini dapat dilakukan, dikenal sebagai "Senescence", yaitu masa proses menjadi tua. Seseorang akan menjadi semakin tua pada awal atau akhir usia enampuluhan, tergantung pada laju kemunduran fisik dan mentalnya dan tergantung pada masing-masing individu yang bersangkutan. Penyebab fisik kemunduran ini merupakan suatu perubahan pada sel-sel tubuh bukan karena penyakit khusus, tetapi karena proses menua. Akibatnya terjadi penurunan pada peranan-peranan sosial dan timbulnya gangguan dalam mencukupi kebutuhan hidupnya sehingga dapat meningkatkan ketergantungan yang memerlukan bantuan orang lain. Kemunduran dapat juga menjadi mempunyai penyebab psikologis. Sikap tidak senang terhadap diri sendiri, orang lain, pekerjaan, dan kehidupan pada umumnya dapat menuju ke keadaan seseorang yang menjadi eksentrik, kurang perhatian, dan terasing secara sosial sehingga penyesuaian dirinya pun menjadi buruk akibatnya, orang menurun secara fisik dan mental sehingga terjadi penurunan dalam melakukan aktivitasnya. Bagaimana seseorang mengalami ketegangan dan stress hidup akan mempengaruhi laju kemunduran itu. Demikian juga halnya bahwa motivasi memainkan peranan penting dalam kemunduran. Dengan adanya gangguan tersebut, menyebabkan lanjut usia menjadi tidak mandiri dan membutuhkan orang lain untuk melakukan aktivitas hidup sehari-hari (Hurlock, 1985; Darmojo, 1995).

Dalam menghadapi kemunduran, mereka membutuhkan bantuan dalam mencapai rasa tentram, nyaman, kehangatan, dan perlakuan yang layak dari lingkungannya. Memberikan perhatian kepada orang lanjut usia dan mengupayakan agar mereka tidak terlalu tergantung kepada orang lain, mampu membantu diri sendiri, menjaga kesehatan diri adalah kewajiban keluarga dan lingkungan (Hurlock, 1985; Pirma, 2005).

Dari berbagai referensi diidentifikasi bahwa lansia memiliki berbagai kebutuhan aktivitas hidup seharihari secara spesifik diantaranya tersedianya sarana dan prasarana dapat meningkatkan mobilitas dan aksesibilitas dalam rangka memenuhi kebutuhan lanjut usia (Depsos, 2002). Menurut Katz, aktivitas kehidupan sehari-hari meliputi kebersihan diri, mandi, berpakaian, makan, buang air kecil, buang air besar dan berpindah, aktivitas sehari-hari instrumental meliputi aktivitas rumah tangga seperti membersihkan dan merapikan kamar dan ruangan, bekerja di dapur seperti menyiapkan makanan, dan aktivitas waktu luang seperti bermain kartu, menonton TV, mendengarkan radio (Darmojo, 1995; Nugroho, 1999).

Selanjutnya menurut Yasa menyampaikan tentang aspek lain yang menjadi motivasi dalam melakukan aktivitas sehari-hari adalah dorongan spritual sebagai bentuk melakukan kebajikan, sebagai bentuk aktualisasi diri, agar tetap dihargai, sejauh kondisi fisik masih memungkinkan, bahkan sebagai usaha untuk memelihara kebugaran (Yasa, 2000).

Menurut Wirakartakusumah (1994), mengungkapkan bahwa lanjut usia masih melakukan aktivitas dengan alasan mencari nafkah, memanfaatkan kemampuan baik fisik dan non fisik yang memang ada manfaatnya serta memenuhi kebutuhan-kebutuhan lain seperti: ingin mengisi waktu luang; status harga diri; atau alasan lain yang dapat timbul karena rasa masih dibutuhkan oleh orang lain.

Menurut O’Brien (1986) mengungkapkan bahwa terdapat dua teori psikologi kerja. Pertama, menrut teori Freudian alasan untuk beraktivitas adalah untuk bertahan hidup. Kedua, menurut teori aktualisasi diri alasan beraktivitas adalah didorong oleh keinginan untuk mengekspresikan kemampuan dan kapasitas yang dimiliki individu.

Panti Sosial Tresna Abdi Dharma Asih Binjai di kelurahan Cengkeh Turi Kecamatan Binjai Utara merupakan unit pelaksanaan teknis di bidang pembinaan, kesejahteraan bagi para usia lanjut/jompo. Dimana mereka mendapatkan tempat tinggal yang layak, diberi jaminan hidup seperti makan, dan pakaian, pemeliharaan kesehatan (seminggu sekali para lanjut usia di periksa kesehatannya dan mereka di beri obat melalui poliklinik yang ada).

Pengisian waktu luang termasuk bimbingan rekreasi, bimbingan sosial, mental, dan agama. Selain itu Panti Werda "Abdi" menyediakan lahan kosong bagi lanjut usia yang memiliki modal membeli bahan sendiri yang bisa digunakan klien lanjut usia untuk bercocok tanam. Dimana hasilnya bisa mereka jual untuk memenuhi kebutuhan mereka yang lainnya sehingga mereka dapat menikmati hari tuanya dengan diliputi ketentraman lahir dan batin.

Penyantunan di dalam panti ini diperuntukkan bagi lanjut usia yang bermasalah atau yang terlantar. Karena Panti sosial ini merupakan tempat pelayanan tanpa pamrih (tidak di pungut bayaran) sama sekali. Oleh sebab itu panti sosial ini selalu penuh dengan orang-orang lanjut usia dari berbagai suku dan agama yang datang dan tinggal dipanti tersebut. Ini terbukti dari data-data yang ada dipanti tersebut.

Keberadaan Panti Sosial Tresna Werda Abdi Dharma Asih Binjai sangat menunjang pelaksanaan program Pemerintah dalam pelayanan kepada masyarakat dalam hal ini usia lanjut. Namun demikian belum banyak diketahui tentang gambaran kebutuhan aktivitas sehari-hari klien lanjut usia yang dapat dilakukan untuk memenuhi kebutuhan hari tuanya dengan baik. Dengan demikian penelitian ini penting 
dilakukan untuk mengindentifikasi bagaimana kebutuhan aktivitas sehari-hari lanjut usia dalam memenuhi kebutuhan hidupnya khususnya yang tinggal di Panti Werda Tresna Abdi Dharma Asih Binjai.

\section{Pertanyaan Penelitian}

Berdasarkan uraian dalam latar belakang tersebut diatas, maka pertanyaan dalam penelitian ini adalah :

a.Mengidentifikasi karakteristik personal klien lanjut usia

b.Mengidentifikasi bagaimana gambaran kebutuhan aktivitas hidup sehari-hari lanjut usia yang tinggal di Panti Werda Tresna Abdi Dharma Asih Binjai

3. Tujuan Penelitian

Tujuan penelitian ini adalah:

a.Untuk mengidentifikasi karakteristik personal klien lanjut usia yang tinggal di UPTD Abdi Dharma Asih Binjai.

b.Untuk mengidentifikasi gambaran kebutuhan aktivitas sehari-hari klien lanjut usia yang tinggal di UPTD Abdi Dharma Asih Binjai.

\section{METODE}

\section{Desain Penelitian}

Pada Penelitian ini digunakan metode penelitian deskriptif yang bertujuan untuk melihat gambaran kebutuhan aktivitas hidup sehari-hari klien lanjut usia di Panti Werda Abdi Dharma Asih Binjai.

Populasi dan Sampel

Populasi

Populasi dalam penelitian ini adalah para klien lansia yang tinggal di UPTD Abdi Dharma Asih Binjai Sumatera Utara dengan jumlah populasi 150 orang (Laporan UPTD Abdi Dharma Asih Binjai, November 2017).

2. Sampel

Pengambilan sampel dilakukan secara simple random sampling. Dimana setiap populasi klien lansia mempunyai kesempatan yang sama untuk diseleksi sebagai sampel untuk mendapatkan sampel yang representatif. Penentuan jumlah sampel dalam penelitian ini didasarkan pada rumusan menurut Arikunto (2002) yaitu $20-25 \%$ dari total populasi.

Dari data survei di Panti Werda Abdi Dharma Asih Binjai terdapat lanjut usia sebanyak 150 orang sehingga dengan menggunakan rumusan tersebut sampel dalam penelitian ini adalah sebanyak 38 orang dengan kriteria sbb: (1). Lanjut usia yang berumur 60 tahun atau lebih dengan orientasi orang, tempat dan waktu yang baik. (2). Lanjut usia yang dapat beraktivitas secara mandiri. (3). Bersedia menjadi responden penelitian. (4). Dapat berkomunikasi dalam bahasa Indonesia yang baik dengan atau tanpa menggunakan alat bantu dengar.

\section{HASIL}

Hasil penelitian tentang Kebutuhan Aktivitas Hidup Sehari-hari Pada Klien Lanjut usia yang Tinggal di
UPTD Abdi Dharma Asih Binjai terhadap 38 orang lanjut usia terdiri dari:.

\section{Karakteristik Responden}

Tabel 1 menunjukkan bahwa berdasarkan karakteristik responden mayoritas responden berusia 6074 tahun sebanyak 27 orang $(71 \%)$ dengan rata-rata berusia 71 tahun $(\mathrm{SD}=5,83)$, mayoritas responden pria (55\%), agama Islam (82\%),dan suku Jawa (50\%). Berdasarkan jenjang pendidikan mayoritas responden ijazah berpendidikan SD (37\%) dan yang tidak sekolah (32\%), pekerjaan responden sebelum masuk ke panti werdha sebahagian besar adalah pegawai swasta (42\%) dan sebahagian lagi adalah petani (40\%).

Tabel 1. Distribusi frekuensi dan persentase berdasarkan karakteristik responden Lanjut usia di UPTD abdi Dharma Asih Binjai $(\mathrm{N}=38)$.

\begin{tabular}{|c|c|c|}
\hline Karakteristik & Frekuensi & $\begin{array}{c}\text { Persentase } \\
(\%)\end{array}$ \\
\hline \multicolumn{3}{|l|}{ Umur } \\
\hline 60-74 & 27 & 71 \\
\hline $75-90$ & 11 & 29 \\
\hline \multicolumn{3}{|l|}{$\begin{array}{l}\text { Mean }=71(\mathrm{SD} \\
=5,83)\end{array}$} \\
\hline Jenis kelamin & 21 & 55 \\
\hline Pria & 17 & 45 \\
\hline \multicolumn{3}{|l|}{ Wanita } \\
\hline Agama & 31 & 82 \\
\hline Islam & 7 & 18 \\
\hline \multicolumn{3}{|l|}{ Kristen } \\
\hline Suku & 19 & 50 \\
\hline Jawa & 7 & 18 \\
\hline Batak & 8 & 21 \\
\hline Aceh & 4 & 11 \\
\hline \multicolumn{3}{|l|}{ Minang } \\
\hline \multicolumn{3}{|l|}{ Pendidikan } \\
\hline Tidak sekolah & 12 & 32 \\
\hline SD & 14 & 37 \\
\hline SMP & 10 & 26 \\
\hline SMU & 2 & 5 \\
\hline \multicolumn{3}{|l|}{ Pekerjaan } \\
\hline sebelumnya & 16 & 42 \\
\hline Pegawai swasta & 15 & 40 \\
\hline Buruh/Petani & 7 & 18 \\
\hline
\end{tabular}

\section{Kebutuhan aktivitas sehari-hari dari aktivitas primer klien lanjut usia di UPTD Abdi Dharma Asih Binjai}

Seluruh responden $(100 \%)$ menyatakan bahwa kebutuhan aktivitas sehari-hari dari aktivitas primer adalah makan 3 kali sehari dengan mendapat makanan tambahan pagi dan sore, kegiatan mandi, menggunakan toilet duduk dan toilet jongkok yang disekitarnya di buat pegangan untuk buang air kecil dan buang air besar, diberi kesempatan melakukan kegiatan ibadah sesuai keyakinan masing-masing, dan tersedianya sarana pemeriksaan kesehatan dan pemberian vitamin perbulannya.

Diantara kebutuhan aktivitas sehari-hari dari kebutuhan aktivitas primer sebagian responden (31-34\%) 
tidak menjadikan kebutuhan istirahat dan kebutuhan berpakaian atau berganti pakaian yang bersih sebagai kebutuhan aktivitas Primer klien lanjut usia yang tinggal di UPTD Abdi Dharma Asih Binjai (tabel 2)

Tabel 2. Distribusi frekuensi dan persentase responden berdasarkan kebutuhan aktivitas sehari-hari dari aktivitas primer di UPTD Abdi Dharma Asih Binjai (N=38)

\begin{tabular}{|c|c|c|}
\hline \multirow{2}{*}{ Pernyataan } & \multicolumn{2}{|c|}{ Frekuensi (Persentase) } \\
\hline & $\begin{array}{c}\mathrm{Ya} \\
\mathrm{n}(\%) \\
\end{array}$ & $\begin{array}{l}\text { Tidak } \\
\mathrm{n}(\%)\end{array}$ \\
\hline $\begin{array}{l}\text { Makan } 3 \text { kali sehari dengan } \\
\text { makanan tambahan pagi }\end{array}$ & $38(100.0)$ & $0(0.0)$ \\
\hline dan sore hari & $38(100.0)$ & $0(0.0)$ \\
\hline $\begin{array}{l}\text { Mandi } 2 \text { kali sehari } \\
\text { menggunakan air bersih } \\
\text { dan sabun mandi }\end{array}$ & $38(100.0)$ & $0(0.0)$ \\
\hline $\begin{array}{l}\text { Menggunakan toilet (WC) } \\
\text { duduk untuk buang air } \\
\text { kecil dan buang air besar. }\end{array}$ & $38(100.0)$ & $0(0.0)$ \\
\hline $\begin{array}{l}\text { Menggunakan toilet (WC) } \\
\text { jongkok dan disekitarnya }\end{array}$ & $38(100.0)$ & $0(0.0)$ \\
\hline $\begin{array}{l}\text { dibuat pegangan untuk } \\
\text { buang air kecil dan air }\end{array}$ & $38(100.0)$ & $0(0.0)$ \\
\hline besar & 26 & $12(31.6)$ \\
\hline Kesempatan melakukan & $(68.4)$ & \\
\hline $\begin{array}{l}\text { ibadah sesuai keyakinan } \\
\text { dan agama masing- } \\
\text { masing }\end{array}$ & $\begin{array}{r}25 \\
(65.8)\end{array}$ & $13(34.2)$ \\
\hline $\begin{array}{l}\text { Tersedianya } \\
\text { pemeriksaan kesehatan } \\
\text { dan pemberian vitamin } \\
\text { perbulan. }\end{array}$ & & \\
\hline $\begin{array}{l}\text { Berpakaian bersih dan } \\
\text { setiap harinya selalu } \\
\text { berganti pakaian. }\end{array}$ & & \\
\hline $\begin{array}{l}\text { Waktu beristirahat } 1-2 \\
\text { jam/hari }\end{array}$ & & \\
\hline
\end{tabular}

3. Kebutuhan aktivitas sehari-hari dari aktivitas rumah tangga klien lanjut usia di UPTD Abdi Dharma Asih Binjai

Tabel 3 menunjukkan hasil penelitian tentang kebutuhan aktivitas sehari-hari dari aktivitas rumah tangga, dimana seluruh responden $(100 \%)$ menyatakan mereka membutuhkan untuk selalu berkumpul bersama dan bercerita dengan teman sepanti. Selanjutnya mayoritas responden $(94,7 \%)$ menyatakan membutuhkan pakaian yang layak untuk dipakai, dan $(81,6 \%)$ menyatakan kebutuhan menggunakan telepon agar dapat menerima kabar dari sanak saudara Hanya sebahagian kecil responden $(10,5 \%)$ yang menyatakan pentingnya tersedianya kebutuhan alat bantu dengar untuk mempertajam pendengaran yang menjadi prioritas kebutuhan aktivitas sehari-hari dari aktivitas rumah tangga.
Tabel 3. Distribusi frekuensi dan persentase responden berdasarkan kebutuhan aktivitas sehari-hari dari aktivitas rumah tangga di UPTD Abdi Dharma Asih Binjai (N=38)

\begin{tabular}{|c|c|c|}
\hline \multirow{2}{*}{ Pernyataan } & \multicolumn{2}{|c|}{ Frekuensi (Persentase) } \\
\hline & $\begin{array}{c}\mathrm{Ya} \\
\mathrm{n}(\%)\end{array}$ & $\begin{array}{l}\text { Tidak } \\
\text { n }(\%)\end{array}$ \\
\hline $\begin{array}{l}\text { Berkumpul bersama dan } \\
\text { bercerita dengan teman }\end{array}$ & $38(100.0)$ & $0(0.0)$ \\
\hline sepanti & $36(94.7)$ & $2(5.3)$ \\
\hline $\begin{array}{l}\text { Tersedianya pakaian yang } \\
\text { layak pakai }\end{array}$ & 31 (81.6) & $7(18.4)$ \\
\hline $\begin{array}{l}\text { Menggunakan telepon agar } \\
\text { dapat menerima kabar }\end{array}$ & $25(65.8)$ & $13(34.2)$ \\
\hline dari sanak keluarga & $18(47.7)$ & $20(52.6)$ \\
\hline $\begin{array}{l}\text { Tersedianya sabun untuk } \\
\text { mencuci dan menggosok } \\
\text { pakaian sendiri }\end{array}$ & $16(57.9)$ & $22(57.9)$ \\
\hline $\begin{array}{l}\text { Berkebun dan beternak di } \\
\text { daerah panti terdapat }\end{array}$ & $16(42.1)$ & $22(57.9)$ \\
\hline lahan yang kosong & $16(42.1)$ & $22(57.9)$ \\
\hline $\begin{array}{l}\text { Tersedianya kacamata } \\
\text { untuk membantu } \\
\text { mempertajam } \\
\text { penglihatan }\end{array}$ & $4(10.5)$ & $34(89.5)$ \\
\hline $\begin{array}{l}\text { Melakukan tugas sehari- } \\
\text { hari; mencuci piring dan } \\
\text { merapikan tempat tidur }\end{array}$ & & \\
\hline $\begin{array}{l}\text { Membersihkan } \\
\text { kamar/ruangan seperti } \\
\text { menyapu dan mengepel } \\
\text { lantai sendiri }\end{array}$ & & \\
\hline $\begin{array}{ll}\text { Tersedianya alat } & \text { Bantu } \\
\text { dengar } & \text { untuk } \\
\text { mempertajam } & \\
\text { pendengaran } & \\
\end{array}$ & & \\
\hline
\end{tabular}

4. Kebutuhan aktivitas sehari-hari dari aktivitas waktu luang klien lanjut usia di UPTD Abdi Dharma Asih Binjai

Dari tabel 4 dapat dilihat bahwa seluruh responden (100\%) menyatakan dapat menyalurkan kegemaran berolahraga dengan fasilitas yang ada dipanti werda seperti senam taichi, senam yoga, dan meditasi yang menjadi prioritas utama dari kebutuhan aktivitas sehari-hari dalam aktivitas waktu luang.

Ada sebanyak $(89,5 \%)$ responden menyatakan terdapat fasilitas sarana hiburan yang benar-benar dapat dinikmati seperti menonton TV, mendengarkan radio, dan bermain kartu yang juga menjadi kebutuhan dari aktivitas waktu luang para lanjut usia, sedangkan hanya sebagian kecil responden sebanyak $(26,3 \%)$ menyatakan bahwa kebutuhan membaca koran, dan adanya kesempatan untuk turut serta dalam kegiatan rekreasi yang diselenggarakan oleh panti minimal tiap bulannya sebagai kebutuhan sehari-hari dari aktivitas waktu luang (Tabel 4).

Tabel 4. Distribusi frekuensi dan persentase responden berdasarkan kebutuhan aktivitas sehari-hari dari aktivitas waktu luang $(\mathrm{N}=38)$ 


\begin{tabular}{|c|c|c|}
\hline \multirow{2}{*}{ Pernyataan } & \multicolumn{2}{|c|}{ Frekuensi (Persentase) } \\
\hline & $\begin{array}{c}\mathrm{Ya} \\
\mathrm{n}(\%)\end{array}$ & $\begin{array}{l}\text { Tidak } \\
\mathrm{n}(\%)\end{array}$ \\
\hline $\begin{array}{l}\text { Menyalurkan kegemaran } \\
\text { berolahraga dengan } \\
\text { fasilitas dipanti werdha ; } \\
\text { senam taichi, yoga dan } \\
\text { meditasi }\end{array}$ & $38(100.0)$ & $4(10.5)$ \\
\hline $\begin{array}{l}\text { Terdapat fasilitas sarana } \\
\text { hiburan yang dapat } \\
\text { dinikmati ;menonton } \\
\text { televisi, mendengarkan } \\
\text { radio dan bermain kartu }\end{array}$ & $10(26.3)$ & $28(73.7)$ \\
\hline $\begin{array}{l}\text { Adanya kesempatan untuk } \\
\text { dalam kegiatan rekreasi } \\
\text { yang diselenggarakan } \\
\text { oleh panti minimal setiap } \\
\text { bulan }\end{array}$ & & \\
\hline $\begin{array}{l}\text { Membaca koran dan koran } \\
\text { ada setiap harinya }\end{array}$ & & \\
\hline
\end{tabular}

\section{PEMBAHASAN}

\section{Kebutuhan aktivitas sehari-hari dari Aktivitas primer}

Hasil penelitian menunjukkan bahwa seluruh responden (100\%) melaporkan kebutuhan aktivitas sehari-hari dari aktivitas primer para lanjut usia di Panti Werda Tresna Abdi Dharma Asih Binjai adalah makan 3 kali sehari dengan mendapat makanan tambahan pagi dan sore, yang disertai dengan kegiatan kebersihan diri mandi, menggunakan toilet duduk atau toilet jongkok yang disekitarnya dibuat pegangan tangan untuk buang air kecil dan air besar, diberi kesempatan melakukan kegiatan ibadah sesuai keyakinan masing-masing, dan tersedianya sarana pemeriksaan kesehatan dan pemberian vitamin yang memadai.

Hasil penelitian ini sesuai dengan pandangan dari Katz (1976) dalam Pudjiastuti (2002) yang mengemukakan bahwa aktivitas kehidupan sehari-hari meliputi kebersihan diri, mandi, berpakaian, makan, buang air kecil dan air besar. Hasil ini seiring dengan penjelasan dari Depsos (2002) tentang alat bantu bagi orang lanjut usia diperlukan dalam rangka meningkatkan mobilitas dan aksesibilatasnya untuk memenuhi kebutuhan-kebutuhannya, dimana seluruh lansia menyatakan menggunakan toilet (WC) duduk setiap mau buang air besar dan buang air kecil dan jika menggunakan toilet jongkok maka dibuat pegangan tangan disekitar WC.

Namun demikian ada (31-34\%) responden yang melaporkan bahwa istirahat dan berganti pakaian yang bersih setiap harinya tidak menjadi kebutuhan aktivitas primer para lanjut usia. Berbeda dengan pandangan dari Evans dan French (dalam Potter \& Perry, 2005) yang menyatakan bahwa para lanjut usia membutuhkan waktu istirahat dan tidur untuk peningkatan derajat kesehatan yang optimal.
Masih dalam penjelasan yang sama disampaikan bahwa adanya keragaman dalam prilaku tidur lanjut usia adalah umum, dan terjadi kecenderungan istirahat siang meningkat secara progresif seiring bertambahnya usia. Peningkatan waktu istirahat siang hari yang dipakai untuk tidur dapat terjadi karena seringnya terbangun pada malam hari. Penjelasan inilah yang mungkin memberikan pernyataan yang berbeda dari responden di Panti Werda Abdi Dharma Asih :Binjai. Klien lanjut usia juga mengungkapkan bahwa waktu istirahat dimanfaatkan untuk bekerja di lahan perkebunan yang disediakan oleh Panti Werda.

O’Brien (1986) juga mengungkapkan mengambil pakaian dari lemari, mengenakan pakaian luar, pakaian dalam, merupakan aktivitas sehari-hari yang dilakukan seseorang lanjut usia dengan ketergantungan dalam aktivitas kehidupan sehari-hari.

Dari pendapat-pendapat diatas dapat dilihat gambaran pada umumnya lansia yang ada di UPTD Abdi Dharma Asih melaksanakan aktivitas primernya dengan baik. Namun pada beberapa kebutuhan sehari-hari lanjut usia dari aktivitas primer perlu mendapat perhatian dari Panti Werda seperti adanya pengadaan telepon, hal ini sesuai dengan laporan lanjut usia di Panti Werda Abdi Dharma Asih Binjai (Juli 2009) yang menyatakanbahwa mereka membutuhkan pengadaan telepon juga.

\section{Kebutuhan aktivitas sehari-hari dari Aktivitas rumah tangga}

Dari hasil penelitian ini diketahui laporan responden menunjukkan dimana seluruh responden $(100 \%)$ menyatakan mereka membutuhkan waktu untuk selalu berkumpul bersama dan bercerita dengan teman sepanti. Selanjutnya responden $(94,7 \%)$ menyatakan membutuhkan pakaian yang layak untuk dipakai, yang menyatakan menggunakan telepon agar dapat menerima kabar dari sanak saudara sebanyak $(81,6 \%)$. Hal ini sesuai dengan apa yang dijelaskan Potter dan Perry (2005) bahwa kemampuan berkomunikasi adalah hal yang menyenangkan bagi lanjut usia yang tinggal di Panti. Hal ini membuka kesempatan pada lanjut usia bertukar perasaan yang dimiliki tentang hal-hal yang lain. Berinteraksi dengan orang lain dapat mengurangi kesepian dan rasa terisolasi, sama halnya dalam menggunakan telepon.

Selanjutnya pendapat Katz (1976 dalam Pudjiastuti, 2002) mengemukakan bahwa aktivitas kehidupan sehari-hari dari aktivitas rumah tangga, mereka membutuhkan mengenakan pakaian yang bersih dan selalu berganti pakaian, Hal ini merupakan bagian dari kegiatan yang dilakukan Depsos (2002) bahwa tersedianya alat bantu bagi orang lanjut usia diperlukan dalam rangka meningkatkan mobilitas dan aksesibilitasnya untuk memenuhi kebutuhankebutuhannya termasuk membutuhkan pakaian yang layak untuk dipakai.

Didalam hasil penelitian ini juga ditemukan bahwa terdapat $(89,5 \%)$ responden menyatakan bahwa tersedianya alat bantu dengar untuk mempertajam pendengaran tidak menjadi prioritas kebutuhan mereka. Hal ini berbeda dengan pendapat-pendapat referensi 
terdahulu diantaranya Kusumah (1994) yang mengungkapkan bahwa lanjut usia masih melakukan aktivitas dengan memanfaatkan kemampuan baik fisik dan non fisik dengan adanya penggunaan alat bantu seperti alat bantu dengar, dan penglihatan juga. Hal ini juga didukung menurut Depsos (2002) menyatakan alat bantu bagi orang lanjut usia diperlukan dalam rangka meningkatkan mobilitas dan aksesibilatasnya untuk memenuhi kebutuhan-kebutuhannya. Selain itu menurut Sulivan \& Shmitz (1994) menyatakan lanjut usia bisa saja melaksanakan tugas tanpa bantuan orang lain akan tetapi tersedia alat bantu yang dapat membantu lansia dalam melaksanakan aktivitasnya. Perbedaan ini dapat dimungkinkan dari keadaan kondisi fisik para lanjut usia saat ini, yang mungkin secara fisik belum menjadi kebutuhan utama.

\section{Kebutuhan aktivitas sehari-hari dari Aktivitas waktu luang}

Tabel 4 menunjukkan seluruh responden (100\%) menyatakan menyalurkan kegemaran berolahraga dengan fasilitas yang ada dipanti werda seperti senam taichi, senam yoga, dan meditasi menjadi prioritas kebutuhan sehari-hari dari aktivitas waktu luang. Hal ini didukung oleh pandangan (Wirakusuma, 2001) yang menyatakan bahwa berolahraga secara teratur dengan jenis olahraga yang sesuai dengan kondisi fisik lanjut usia dapat menjadi suatu aktivitas waktu luang bagi lanjut usia agar dapat mengurangi atau mencegah berbagai penyakit yang umum menyerang usia lanjut karena proses penuaan. Disamping itu latihan dan olahraga memberikan perasaan nyaman dan sehat dalam beraktivitas di waktu luang apalagi bagi mereka yang memasuki usia lanjut (Hartono, 2001). Pernyataan ini beralasan karena sama dengan pendapat yang dikemukakan oleh Zickov (1991) bahwa olahraga merupakan salah satu faktor utama untuk tetap aktif di usia lanjut.

Mayoritas responden $(89.5 \%)$ menyatakan mengisi waktu luang dengan memanfaatkan fasilitas sarana hiburan yang benar-benar dapat dinikmati seperti menonton TV, mendengarkan radio dan bermain kartu. Hasil penelitian ini didukung oleh pendapat keliat (1995) bahwa aktivitas kelompok dapat menghilangkan rasa bosan atau stress individu yang salah satunya dengan berjalan-jalan, mendengarkan radio atau menonton televisi. Pendapat yang sama juga dikemukakan oleh Darmojo (1995) tentang aktivitas luang yang dapat digunakan lanjut usia adalah menonton TV, mendengarkan radio, bermain kartu dan lain-lain.

\section{KESIMPULAN}

Secara umum usia responden pada rentang 6081 tahun dan mayoritas responden berusia 60-74 tahun sebanyak 27 orang $(71 \%)$ dengan rata-rata berusia 71 tahun $(\mathrm{SD}=5,83)$, mayoritas responden pria $(55 \%)$, agama Islam (82\%), dan suku Jawa (50\%). Latar belakang pendidikan SD (37\%) dan yang tidak sekolah (32\%), pekerjaan responden sebelumnya adalah wiraswasta (42\%) dan sebahagian lagi adalah petani (40\%).
Berdasarkan hasil penelitian (100\%) responden memberikan respon bahwa kebutuhan aktivitas yang mereka lakukan terbesar yang mereka butuhkan adalah kebutuhan akan aktivitas primer makan 3 kali sehari dengan mendapat makanan tambahan pagi dan sore, kegiatan mandi, menggunakan toilet duduk dan toilet jongkok yang disekitarnya di buat pegangan untuk buang air kecil dan buang air besar, diberi kesempatan melakukan kegiatan ibadah sesuai keyakinan masingmasing, dan tersedianya sarana pemeriksaan kesehatan dan pemberian vitamin perbulannya.

Aktivitas rumahtangga seluruh responden (100\%) menyatakan mereka membutuhkan untuk selalu berkumpul bersama dan bercerita dengan teman sepanti, responden $(94,7 \%)$ menyatakan membutuhkan pakaian yang layak untuk dipakai, dan $(81,6 \%)$ menyatakan kebutuhan menggunakan telepon agar dapat menerima kabar dari sanak saudara.

Sedangkan untuk aktivitas waktu luang seluruh responden (100\%) menyatakan dapat menyalurkan kegemaran berolahraga dengan fasilitas yang ada dipanti werda seperti senam taichi, senam yoga, dan meditasi. Responden $(89,5 \%)$ menyatakan terdapat fasilitas sarana hiburan yang benar-benar dapat dinikmati seperti menonton TV, mendengarkan radio, dan bermain kartu yang juga menjadi kebutuhan dari aktivitas waktu luang para lanjut usia.

\section{Rekomendasi untuk keluarga/masyarakat}

Perlu ditingkatkan kesadaran keluarga untuk memperhatikan kebutuhan sehari-hari lanjut usia terutama akan kebutuhan aktivitasnya meskipun lanjut usia tersebut tinggal dipanti werda karena bagi mereka dukungan dari keluarga sangat penting di dalam memenuhi kebutuhannya. Bagi mereka pribadi setelah memasuki usia lanjut, tidak terlalu memikirkan untuk mencari kebutuhan hidup yang berlebih. Yang terpenting bagi mereka hanyalah bagaimana memenuhi kebutuhan aktivitasnya baik aktivitas primer, aktivitas rumah tangga, tidak terlalu memikirkan aktivitas waktu luangnya dimana waktu istirahat dimanfaatkan untuk beraktivitas.

SARAN

\section{Untuk Perawat Komunitas}

Dalam pengembangan profesionalisme keperawatan di berbagai tatanan pelayanan kesehatan, khususnya keperawatan komunitas, keluarga, dan gerontik untuk dapat menginformasikan hasil penelitian ini sebagai evidence dan memfasilitasi klien lanjut usia agar dapat mengembangkan kebutuhan aktivitas hidup sehari-harinya.

\section{DAFTAR PUSTAKA}

Arikunto, S. (2002). Prosedur penelitian suatu pendekatan praktek. Jakarta: Rineka Cipta.

Azwar, S. (1997). Reabilitas dan Validitas. Yogyakarta: Pustaka Pelajar.

Darmojo, B. (2004). Tua tidak harus renta. Dibuka pada website http: //www.suara merdeka.com/harian/0406/15/ked07.htm pada tanggal 6 April 2005. 
Depkes RI. (1992). Pedoman pembinaan kesehatan lanjut usia bagi petugas kesehatan. Jakarta: Direktorat Bina Kesehatan Keluarga.

Depkes RI. (2001). Pedoman pembinaan kesehatan lanjut usia bagi petugas kesehatan: Kebijakan program. Jakarta: Direktorat Bina Kesehatan Keluarga.

Depsos. (2002). Lanjut usia dalam data dan demografi. Jakarta: Direktorat Bina Pelayanan Sosial Lanjut Usia.

Effendi, N. (1998). Dasar-dasar keperawatan kesehatan masyarakat. Jakarta: EGC.

Friedman, M.M. (1998). Keperawatan keluarga: teori dan praktek, edisi ketiga. Jakarta: EGC.

Hartono. (2001). Upaya-upaya hidup sehat sampai tua. Jakarta: Depot Informasi Obat.

Hurlock, E. B. (2002). Psikologi perkembangan: suatu pendekatan sepanjang rentang kehidupan. Surabaya: Erlangga.
Kasiyanto, M. J. (1996). Menuju bahagia di usia lanjut. Jakarta: Pusat Kajian Nasional Masalah Usia Lanjut.

Kuntjoro, Z. S. (2002). Pendekatan-pendekatan dalam pelayanan geriatric. Diambil dari website http: // www. e-psikologi. com/usia/130502. htm.

Kusumoputro, S. (2002). Dukungan sosial pada lansia. Diambil dari website http: // www. e-psikologi. com/usia/160802. htm.

Mundiharno, (1997). Lansia Indonesia awal Abad 21: Sebuah Tinjauan Demografis, Warta Demografi edisi khusus thn. 1997, hal. 25-29.

Notoadmodjo, S. (1993). Metodologi penelitian kesehatan, Jakarta: Rineka Cipta.

Nugroho, W. (2000). Perawatan lanjut usia. Jakarta: EGC Nursalam. (2003). Konsep dan penerapan metodologi penelitian ilmu keperawatan Jakarta: Salemba Medika. 